\title{
Editorial: IZA Journal of Labor Economics
}

Pierre Cahuc, V Joseph Hotz, Anne C Gielen and Klaus F Zimmermann

Correspondence: izajole@iza.org Editors of the IZA Journal of Labor Economics
The editors, Pierre Cahuc and V. Joseph Hotz, are pleased to present the IZA Journal of Labor Economics (IZAJOLE), a new online journal that covers research in all areas of labor economics. Labor economics is an ever-expanding field ever expanding into new domains. This Journal provides a venue not only for such traditional labor economic topics as labor supply and demand, discrimination, and earnings and inequality, but also for topics that have attracted more and more of the attention of the field. These include allocation of time and human well-being, the economic role of non-cognitive skills, and the economic impact of various aspects of health on market and nonmarket activities. By publishing research on these and other topics, the IZA Journal of Labor Economics seeks to further our understanding of these varied and complex issues and to be a major source of information to the scientific and broader communities about the latest developments in this important field within economics.

We aim to publish high quality theoretical and applied contributions on both microeconomic and macroeconomic oriented labor-related topics and we especially encourage submissions in subject areas that are closely linked to the various IZA program areas. The Journal is committed to an expeditious decision making and publication process, where acceptance/rejection decisions are expected to be made within one month, and publication is expected within one month after a decision has been made. To help us meet these goals, we have assembled an outstanding board of editors, consisting of leading experts in the area of labor economics.

We are very enthusiastic about this new venture, and we hope that, over the coming years, you will read the Journal on a regular basis and submit your manuscripts to us for possible inclusion in its future issues.

\section{Pierre Cahuc \\ V. Joseph Hotz}

\section{Editors}

Anne C. Gielen

Managing Editor:

Klaus F. Zimmermann

Editor-in-Chief for the Journal Series 
Submit your manuscript to a SpringerOpen ${ }^{\circ}$ journal and benefit from:

- Convenient online submission

- Rigorous peer review

- Immediate publication on acceptance

- Open access: articles freely available online

- High visibility within the field

Retaining the copyright to your article

Submit your next manuscript at $>$ springeropen.com 